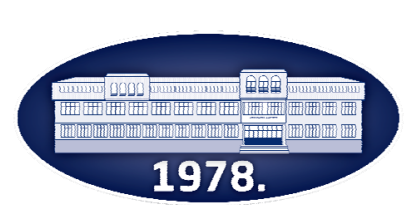

Publisher: Faculty of Agronomy Čačak

\title{
In vitro propagation and medium-term conservation of autochthonous plum cultivar 'Crvena Ranka'
}

\author{
Tatjana Vujović* , Darko Jevremović, Tatjana Marjanović, Ivana Glišić \\ Fruit Research Institute, Kralja Petra I no. 9, 32000 Čačak, Republic of Serbia \\ *Corresponding author: tatjanal@ftn.kg.ac.rs
}

Received 7 August 2020; Accepted 17 September 2020

\begin{abstract}
A B S T R A C T
In vitro strategies for the propagation and conservation of indigenous species contribute to the sustainable use of plant diversity and are essential for breeding programs as well. In this study, we established an efficient protocol for the micropropagation of autochthonous plum 'Crvena Ranka' and examined the survival and regrowth capacity of in vitro shoots after 3, 6 and 9 months of cold storage (CS) at +5 oC in total darkness. Aseptic culture was established on the Murashige and Skoog medium containing 2 mg l-1 BA, $0.5 \mathrm{mg} \mathrm{l-1}$ IBA and $0.1 \mathrm{mg} \mathrm{l-1}$ GA3 (leaf rosette initiation being 68.8\%). During in vitro propagation on the medium of constant hormonal composition, a significant increase in the multiplication index was observed in the third subculture, whereupon it was mainly stable until the fifth subculture. The effect of BA concentration and/or type of auxins (IBA or NAA) on multiplication parameters, as well as on fresh and dry weights of shoots was evaluated. BA at 1 mg l-1 in combination with NAA significantly increased shoot multiplication parameters. The effect of auxins on rooting parameters was monitored as well. Shoots cultured on the medium supplemented with NAA also displayed higher rooting ability (60\%), in comparison with those grown on the medium containing IBA at the same concentration (20\%). In vitro shoots can be conserved over the medium term under CS conditions up to six months. High survival was achieved after three (94\%) and six months (82.5\%), while severe signs of necrosis $(100 \%)$ were noticed after nine months of conservation. Shoots subcultured under standard growth conditions after CS promptly regained their morphology although their capacity for multiplication and rooting was slightly lower than that of non-cold-stored shoots.

Keywords: Prunus domestica L., in vitro, multiplication, rooting, cold storage, viability.
\end{abstract}

\section{И 3 В О д}

In vitro стратегије размножавања и конзервације угрожених врста веома су значајне за одрживо коришћење биљних ресурса, али и за традиционалне и савремене програме оплемењивања. У овом раду је успостављен ефикасан протокол за микропропагацију аутохтоне шљиве Црвена ранка и испитана је могућност средње дугог чувања (3, 6 и 9 месеци) іn vitro гајених изданака на +5 оС у условима потпуног мрака - “cold storage” (CS) техником. Асептична култура је успостављена гајењем експлантата бочних пупољака на Murashige и Skoog medijumu ca 2 mg l-1 BA, 0,5 mg l-1 IBA и 0,1 mg l-1 GA3, где је 68,8\% експлантата иницирало розету. Током in vitro размножавања на медијуму константног хормонског састава уочено је значајно повећање индекса мултипликације у трећој супкултури, после чега се његова вредност није значајно мењала до пете супкултуре. Испитан је утицај концентрације цитокинина ВА и/или врсте ауксина (IBA или NAA) на параметре мултипликације, као и на свежу и суву масу изданака и показано је да ВА у концентрацији 1 mg l-1 примењен у комбинацији са NAA уместо IBA доводи до значајног повећања параметара умножавања изданака. Праћен је и утицај врсте ауксина на ожиљавање изданака. Изданци гајени на медијуму са NAA ожиљавани су боље (60\%) у односу на оне гајене на медијуму са IBA (20\%). Изданци ове сорте шљиве се могу чувати у CS условима до 6 месеци. Највеће преживљавање (94\%) изданака постигнуто је после 3 месеца гајења изданака у CS uslovima. После 6 месеци, CS преживљавање је било 82,5\%, док су сви изданци потпуно некротирали после 9 месеци гајења у условима CS. Потпуно и делимично вијабилни изданци су после преношења на свеж медијум и гајења у стандардним in vitro условима врло брзо повратили нормалну морфологију, мада су мултипликација и ожиљавање изданака били значајно нижи у односу на изданке који нису гајени у CS условима.

Кључне речи: Prunus domestica L., in vitro, мултипликација, ожиљавање, хладно чување, вијабилност.

\section{Introduction}

The conservation of plant species, particularly of those important for agriculture, has now reached very high importance in ensuring the sustainable utilization of biological resources by preventing further losses of plant diversity. Namely, breeding activities during the second half of the 20th century led to the commercial introduction of a large number of improved cultivars, which progressively replaced old, locally adapted and traditionally grown cultivars (Sonnino, 2017). Other causes of genetic erosion are climate change and the long-term inoculum pressure of numerous pathogens. For these reasons, the conservation, maintenance, availability, exchange and sustainable use of the diversity of existing plant genetic resources (PGRs) for food and agriculture are the issues of greatest importance.

Plums are among Serbia's most traditional fruit crops, with about 48 million trees of numerous cultivars 
(Glišić, 2015), ranging from autochthonous to newly bred ones. Indigenous cultivars are part of the Serbian tradition, customs, legacy, and cultural identity. In addition to providing the genetic basis for clonal selection, they are also used in different breeding programs aimed at developing new plum cultivars as well as new plum, apricot and peach rootstocks (Milošević et al., 2010). However, the majority of these cultivars are being seriously threatened and are slowly disappearing from orchards. Among autochthonous cultivars, 'Crvena Ranka' stands out as a sharka-tolerant cultivar mostly used for producing supreme quality plum brandies (Popović et al., 2015). Fruits of some local genotypes are suitable for fresh use (Milošević and Milošević, 2012). In recent years, there has been an increased interest in establishing new commercial orchards of this valuable cultivar. Therefore, it is of vital importance to develop protocols for the clonal propagation of selected genotypes to obtain a large number of true-to-type plants from a few initial plants, in the shortest period of time. The rapid production of highquality, disease-free and uniform planting stock is only possible through micropropagation. However, long-term successive subculture of in vitro plants on a fresh medium and their maintenance under normal growth conditions can be followed by a decrease in or loss of the cultures' morphogenetic potential as well as by an increase in the possibility of genetic alterations or propagating material loss due to human errors or microbial contamination (Chauhan et al., 2019). On the other hand, tissue culture technology also enables the conservation of plant genetic resources for either short, medium or long term, depending on the requirement as well as on the technique applied (Engelmann, 1997). In vitro conservation of vegetatively propagated species such as fruit tree species is complementary to field gene banks, which, along with in situ conservation measures, provide an integrated conservation strategy (Rajasekharan and Sahijram, 2015).

The aim of this paper was to establish an efficient protocol for the in vitro propagation of autochthonous plum cultivar 'Crvena Ranka' by optimizing multiplication and rooting stages, and to examine the possibility of mid-term conservation of this genotype using the slow growth storage method, which involved temperature reduction pooled with the maintenance of cultures under dark conditions.

\section{Material and methods}

\section{Plant material and establishment of aseptic culture}

A selected clone of autochthonous plum cultivar 'Crvena Ranka' (Prunus domestica L.) originating from Gledić Mountains was used as the source of initial explants for in vitro culture. Aseptic culture was established using actively growing axillary leaf buds taken from branches during the spring. The surface sterilization procedure involved washing explants under running water for $2 \mathrm{~h}$, sterilization in $70 \%$ ethanol ( $1 \mathrm{~min})$, and 15 minute-soaking in $10 \%(\mathrm{v} / \mathrm{v})$ commercial bleach solution $(0.4 \%, w / v$, final concentration of sodium hypochlorite), followed by triple rinsing ( $5 \mathrm{~min}$ each) with sterile distilled water. Buds were isolated under a stereomicroscope and placed onto the Murashige and Skoog (1962) medium (MS) containing $2 \mathrm{mg} \mathrm{l}^{-1} \mathrm{~N} 6$-benzyladenine (BA), $0.5 \mathrm{mg}$ $\mathrm{l}^{-1}$ indole-3-butyric acid (IBA) and $0.1 \mathrm{mg} \mathrm{l}^{-1}$ gibberellic acid ( $\left.\mathrm{GA}_{3}\right)$. After four weeks, rates of contaminated and necrotic buds and of those which initiated sterile leaf rosettes were noted.

\section{Shoot multiplication and rooting}

Upon establishment of aseptic culture, single uniform shoots were multiplied on the MS medium of constant plant growth regulator (PGR) composition: 1 $\mathrm{mg} \mathrm{l}^{-1} \mathrm{BA}, 0.1 \mathrm{mg} \mathrm{l}^{-1}$ IBA and $0.1 \mathrm{mg} \mathrm{l}^{-1} \mathrm{GA}_{3}$. The multiplication medium contained $30 \mathrm{~g} \mathrm{l}^{-1}$ sucrose and 7 $\mathrm{g} \mathrm{l}^{-1}$ agar. The $\mathrm{pH}$ value was adjusted to 5.7 before autoclaving at $121^{\circ} \mathrm{C}, 150 \mathrm{kPa}$ for $20 \mathrm{~min}$. Shoots were repeatedly subcultured five times at a constant fourweek subculture interval. Multiplication parameters, i.e. the multiplication index and lengths of axial and lateral shoots were determined upon each subculture. The multiplication index was defined as the number of newly formed axillary shoots $(>0.5 \mathrm{~cm})$ per initial shoot tip recorded after the stated subculture interval.

To optimize multiplication, the influence of BA concentration and type of auxins [IBA or 1naphthaleneacetic acid (NAA)] on the multiplication capacity and shoot quality were examined in the sixth subculture. The PGR combinations used in this stage of micropropagation are given in Tables 2 and 3. Shoots were subcultured twice at a 28 day-interval on the medium of the same PGR composition, and therefore all parameters were determined in the second subculture. The following multiplication parameters were monitored: multiplication index, length of axial shoots, length of lateral shoots, number of leaves on axial shoots and number of leaves on lateral shoots. After removal from the medium, shoots were washed in distilled water and dried with filter paper, and their fresh weight (FW) was determined. For dry weight (DW), shoots were dried in an oven at $65-70^{\circ} \mathrm{C}$ for 48 h.

Rooting was performed on the MS medium with mineral salts reduced to $1 / 2$-strength and organic complex unchanged. Rooting treatments included two PGR combinations, as indicated in Table 4. The percentage of rooted plants was determined after 28 days along with the number and length of roots, and height of rooted plants.

Each treatment in multiplication and rooting stages included 45 uniform shoots (three replicates of three culture vessels with five shoots). Shoot cultures were grown in $100 \mathrm{ml}$ culture vessels containing $50 \mathrm{ml}$ of multiplication or rooting medium, at $23 \pm 1^{\circ} \mathrm{C}$ and 16-hphotoperiod (light intensity, $41 \mu \mathrm{mol} \mathrm{m}^{-2} \mathrm{~s}^{-1}$ ).

\section{Slow growth storage and repropagation}

The slow growth experiment was performed with shoots taken from proliferated cultures and planted on a fresh multiplication medium (previously determined to be the most suitable for propagation) in Erlenmeyer flasks closed with cellulose stoppers. Explants were placed in darkness in a growth chamber at $5{ }^{\circ} \mathrm{C}$ (cold storage, CS) and their viability was examined after three, six, and nine months. After the respective periods of CS, the cultures were transferred to a growth chamber for seven days and the viability of shoots for further propagation (percentages of fully viable shoots, partially viable shoots and fully necrotic shoots) was determined. Each treatment was performed with three 
replicates of five culture vessels with five uniform shoots (75 plants for each treatment). After each CS period, survived shoots were subcultured for three consecutive four-week cycles under standard growing conditions. The number of shoots per explant and their lengths were recorded at the end of the third subculture. After multiplication, cold-stored shoots were rooted on the above-described rooting media, and rooting parameters (rate of rooting, number and length of roots, and height of rooted plants) were determined.

\section{Statistical analysis}

All data were analyzed by ANOVA, followed by Duncan's Multiple Range Test $(\mathrm{P}<0.05)$ for means separation. The data presented in percentages were subjected to arcsine transformation.

\section{Results and discussion}

Microbial contaminants present a major challenge in in vitro culture technology. Although most of the sterilizing agents used for the initiation and maintenance of viable in vitro cultures show toxicity to plant tissues, it is possible to minimize explant loss and achieve high survival rates by optimizing the concentration of sterilants and the duration of explant exposure to them. In our material, $70 \%$ ethanol in combination with $10 \%$ bleach, as the source of sodium hypochlorite, proved effective in sterilizing explants taken from open field-grown plants (Fig. 1a). The use of a two-step sterilization procedure has proved beneficial in certain plant species including fruit tree species (Ružić et al., 2010). However, we obtained a markedly higher rate of leaf rosette initiation (68.8\%; Fig. $1 \mathrm{a}$ and $1 \mathrm{~b})$ and a lower contamination rate (8.3\%) in comparison with the rates obtained by Ružić et al. (2010) in three vegetative rootstocks for cherry, plum and pear (28.3-46.9\% and 48.1-71.7\%, respectively), although they took initial explants from screenhousegrown plants. Possible reasons for better results in our experiment are a slightly prolonged bleach treatment (15 min in comparison with $12 \mathrm{~min}$ ) and treatment of mother plants with fungicides just before taking initial explants.

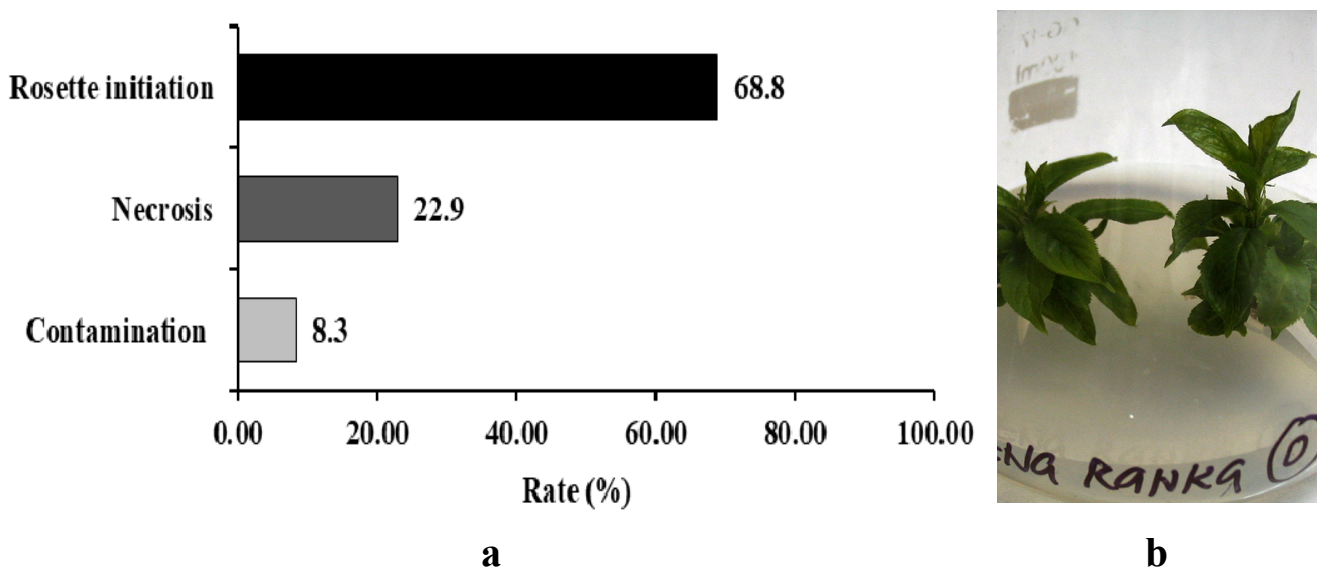

Figure 1. Establishment of aseptic culture (a) and initiated leaf rosettes (b)

After the establishment of aseptic culture, shoots of 'Crvena Ranka' were multiplied on the MS medium of constant PGR composition, previously determined to be the most optimal for the multiplication of other plum genotypes (Vujović et al., 2018). Monitoring of the regeneration ability of shoots in five successive subcultures, expressed through the multiplication index and lengths of axial and lateral shoots, revealed the increase in shoot formation capacity over repeated subcultures (Table 1).

Table 1.

Shoot multiplication parameters of 'Crvena Ranka' in five successive subcultures after rosette initiation on the MS medium containing $1.0 \mathrm{mg} \mathrm{l}^{-1} \mathrm{BA}, 0.1 \mathrm{mg} \mathrm{l}^{-1} \mathrm{IBA}$ and $0.1 \mathrm{mg} \mathrm{l}^{-1} \mathrm{GA}_{3}$

\begin{tabular}{cccc}
\hline Subculture & Multiplication index & $\begin{array}{c}\text { Length of axial } \\
\text { shoots }(\mathrm{mm})\end{array}$ & $\begin{array}{c}\text { Length of lateral shoots } \\
(\mathrm{mm})\end{array}$ \\
\hline $1^{\text {st }}$ & $2.0 \mathrm{~b}^{1}$ & 9.5 & $5.7 \mathrm{c}$ \\
$2^{\text {nd }}$ & $2.1 \mathrm{~b}$ & 10.2 & $6.5 \mathrm{abc}$ \\
$3^{\text {rd }}$ & $2.4 \mathrm{a}$ & 10.1 & $7.3 \mathrm{a}$ \\
$4^{\text {th }}$ & $2.2 \mathrm{ab}$ & 10.2 & $6.2 \mathrm{bc}$ \\
$5^{\text {th }}$ & $2.5 \mathrm{a}$ & 10.0 & $6.8 \mathrm{ab}$ \\
\hline & $\mathrm{P}<0.05$ & $\mathrm{~ns}$ & $\mathrm{P}<0.05$ \\
\hline
\end{tabular}

1 Mean values of multiplication parameters followed by the same lowercase letters within the same column are not significantly different according to Duncan's Multiple Range Test

A significant increase in the shoot number formed (2.4) occurred in the third subculture and remained constant afterwards. Similarly, Debnath (2004) noticed that, in dwarf raspberry, the multiplication index as well as shoot length and leaf number increased with subculturing up to the third subculture, and then remained constant. As determined by Grant and Hammatt (1999), the rates of increase in shoot 
production during micropropagation are a function of the total time spent in culture and could be attributed to the rejuvenation of mature tissues during in vitro culture. Contrary to these results, a sharp decline in shoot formation capacity was noticed after the third subculture in Vitis vinifera L. 'Napoleón' (Ibáñez et al., 2003), the second subculture in Sterculia urens Roxb. (Hussain et al., 2007) and even after the first subculture in 'Gisela 6' and 'Fereley Jaspi' (Vujović et al., 2012). As regards the length of axial shoots, no significant variations were observed among successive subcultures, while after a significant increase in the second subculture the length of lateral shoots was stable until the last subculture (Table 1). Hamad and Taha (2008) also reported that the subcultures improved shoot elongation during short-lasting incubation ( 30 or 45 days).

The work towards improving the propagation capacity of shoots involved the examination of the influence of BA concentration and/or type of auxins (IBA or NAA) on the multiplication capacity and fresh and dry weights of shoots in the sixth subculture. Reducing the cytokinin concentration in later subcultures could improve the shoot regeneration ability of in vitro cultures during repeated subculturing (Hussain et al., 2007). In the case of 'Crvena Ranka' plum, reducing the $\mathrm{BA}$ concentration to $0.5 \mathrm{mg} \mathrm{l}^{-1}$ in combination with IBA did not improve the multiplication capacity of shoots (Table 2). A similar positive response for shoot induction and shoot multiplication on the media containing 0.5 or $1 \mathrm{mg} \mathrm{l}^{-1}$ BA in combination with $0.1 \mathrm{mg} \mathrm{l}^{-1}$ IBA was also obtained in 'Stanley' (Wolella, 2017). Hence, the use of the lower concentration of BA was recommended because it was more economical. In our experiments, the decrease in BA concentration in combination with IBA significantly improved the length of both axial and lateral shoots and the number of leaves (Fig. 2a) in comparison with the medium containing $1 \mathrm{mg} \mathrm{l}^{-1} \mathrm{BA}$ (Fig. 2c), which justifies the use of lower concentrations of this PGR. As regards the multiplication index, similar results were obtained on the medium containing 0.5 mg l-1 BA in combination with NAA, although this PGR combination did not significantly affect shoot length (Table 2; Fig. 2b). Taking into account all shoot multiplication parameters, significant improvement was achieved when $1 \mathrm{mg} \mathrm{l}^{-1} \mathrm{BA}$ was combined with NAA instead of IBA (Table 2; Fig. 2d). This PGR combination was determined to be the most suitable for the multiplication of other Prunus genotypes, such as sour cherry 'Čačanski Rubin' (Vujović et al., 2013).

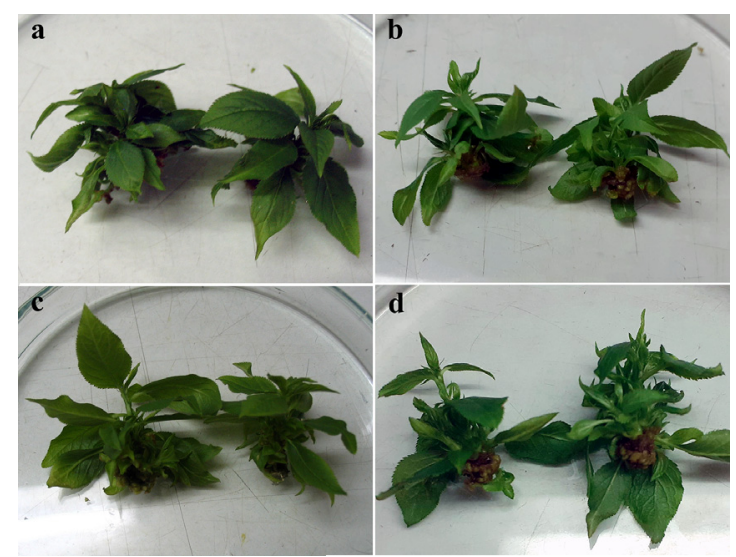

Figure 2. Shoots of 'Crvena Ranka' grown on media containing: $0.5 \mathrm{mg} \mathrm{l}^{-1} \mathrm{BA}$ in combination with $1 \mathrm{mg} \mathrm{l^{-1 }}$ IBA (a) or NAA (b); and $1 \mathrm{mg} \mathrm{l}^{-1} \mathrm{BA}$ in combination with $1 \mathrm{mg} \mathrm{l}^{-1}$ IBA (c) or NAA (d)

Table 2.

Shoot multiplication parameters of 'Crvena Ranka' on MS media of different PGR compositions in the sixth subculture

\begin{tabular}{cccccc}
\hline $\begin{array}{c}\text { PGR concentration } \\
\left(\mathrm{mg} \mathrm{l}^{-1}\right)^{*}\end{array}$ & $\begin{array}{c}\text { Multiplication } \\
\text { index }\end{array}$ & $\begin{array}{c}\text { Length of axial } \\
\text { shoots }(\mathrm{mm})\end{array}$ & $\begin{array}{c}\text { Length of lateral } \\
\text { shoots }(\mathrm{mm})\end{array}$ & $\begin{array}{c}\text { No. of leaves } \\
\text { on axial shoots }\end{array}$ & $\begin{array}{c}\text { No. of leaves on } \\
\text { lateral shoots }\end{array}$ \\
\hline BA 0.5 + IBA 0.1 & $2.9 \mathrm{~b}^{1}$ & $14.5 \mathrm{a}$ & $6.5 \mathrm{~b}$ & $12.8 \mathrm{~b}$ & $6.2 \mathrm{~b}$ \\
BA 0.5 + NAA 0.1 & $2.8 \mathrm{~b}$ & $11.9 \mathrm{~b}$ & $5.9 \mathrm{c}$ & $11.7 \mathrm{c}$ & $7.0 \mathrm{a}$ \\
BA 1 + IBA 0.1 & $2.7 \mathrm{~b}$ & $12.0 \mathrm{~b}$ & $5.6 \mathrm{c}$ & $10.8 \mathrm{~d}$ & $4.9 \mathrm{c}$ \\
BA 1+ NAA 0.1 & $3.3 \mathrm{a}$ & $14.9 \mathrm{a}$ & $7.0 \mathrm{a}$ & $14.6 \mathrm{a}$ & $6.2 \mathrm{~b}$ \\
\hline
\end{tabular}

${ }^{*} \mathrm{PGR}$ - Plant growth regulator (all tested combinations included $0.1 \mathrm{mg} \mathrm{l}^{-1} \mathrm{GA}_{3}$ ); ${ }^{1}$ Mean values of multiplication parameters followed by the same lowercase letters within the same column are not significantly different according to Duncan's Multiple Range Test at $P$ $<0.05$

Although shoots multiplied on all tested media had normal morphology and were well developed, their growth parameters were significantly different. In general, shoots grown on media with NAA had higher fresh and dry weights in comparison with those grown on IBA-containing media (Table 3). The highest FW and
DW of axial shoots were obtained when NAA was combined with $0.5 \mathrm{mg} \mathrm{l}^{-1} \mathrm{BA}$, while for lateral shoots these parameters were the highest in combination with $1 \mathrm{mg} \mathrm{l}^{-1} \mathrm{BA}$. In contrast, shoots grown on the initially used medium containing $1 \mathrm{mg} \mathrm{l}^{-1} \mathrm{BA}$ and $0.1 \mathrm{mg} \mathrm{l}^{-1}$ IBA had significantly higher FW and DW of callus. 
Table 3.

Fresh and dry weights of calluses and shoots of 'Crvena Ranka' on MS media of different PGR compositions in the sixth subculture

\begin{tabular}{|c|c|c|c|c|c|c|}
\hline \multirow[b]{2}{*}{$\begin{array}{l}\text { PGR concentration } \\
\left(\mathrm{mg} \mathrm{l}^{-1}\right)^{*}\end{array}$} & \multicolumn{3}{|c|}{ Shoot fresh weight (mg) } & \multicolumn{3}{|c|}{ Shoot dry weight (mg) } \\
\hline & Callus & Axial shoots & $\begin{array}{l}\text { Lateral } \\
\text { shoots }\end{array}$ & Callus & Axial shoots & $\begin{array}{l}\text { Lateral } \\
\text { shoots }\end{array}$ \\
\hline BA 0.5 + IBA 0.1 & $48.1 b^{1}$ & $139.3 \mathrm{~b}$ & $27.5 \mathrm{~b}$ & $8.0 \mathrm{~b}$ & $29.0 \mathrm{ab}$ & $5.9 \mathrm{ab}$ \\
\hline BA 0.5 + NAA 0.1 & $47.7 \mathrm{~b}$ & $154.2 \mathrm{a}$ & $21.6 \mathrm{c}$ & $9.4 \mathrm{ab}$ & $32.1 \mathrm{a}$ & $5.5 \mathrm{ab}$ \\
\hline BA 1 + IBA 0.1 & $65.1 \mathrm{a}$ & $154.2 \mathrm{a}$ & $24.2 \mathrm{c}$ & $10.8 \mathrm{a}$ & $27.5 \mathrm{~b}$ & $4.4 \mathrm{~b}$ \\
\hline BA 1+ NAA 0.1 & $36.9 \mathrm{~b}$ & $144.9 \mathrm{ab}$ & $29.9 \mathrm{a}$ & $6.9 \mathrm{~b}$ & $29.0 \mathrm{ab}$ & $6.2 \mathrm{a}$ \\
\hline
\end{tabular}

${ }^{*}$ PGR - Plant growth regulator (all tested combinations included $0.1 \mathrm{mg} \mathrm{l}^{-1} \mathrm{GA}_{3}$ ); ${ }^{1}$ Mean values of multiplication parameters followed by the same lowercase letters within the same column are not significantly different according to Duncan's Multiple Range Test at $P$ $<0.05$

European plums usually exhibit poor rooting ability of in vitro induced shoots, which could be the major drawback in commercial micropropagation. Use of NAA at higher concentrations instead of IBA can increase rooting efficiency (Tian et al., 2007), which was confirmed in our research. Namely, in this study, rooting efficiency was increased from $20 \%$ to $60 \%$ and there was an increase in shoot length from $9.8 \mathrm{~mm}$ to $11.3 \mathrm{~mm}$ and in root length from $11.2 \mathrm{~mm}$ to $22 \mathrm{~mm}$, when shoots were cultured on the medium having NAA instead of IBA at the same concentration (Table 4).

Table 4.

Rooting parameters of non-preserved and cold-stored shoots of 'Crvena Ranka'

\begin{tabular}{|c|c|c|c|c|}
\hline $\begin{array}{l}\text { PGR concentration (mg } \\
\left.\mathrm{l}^{-1}\right)^{*}\end{array}$ & $\begin{array}{c}\text { Rooting rate } \\
(\%)\end{array}$ & No. of roots & $\begin{array}{l}\text { Root length } \\
(\mathrm{mm})\end{array}$ & $\begin{array}{l}\text { Rooted shoot } \\
\text { length (mm) }\end{array}$ \\
\hline \multicolumn{5}{|c|}{ Non-cold-stored shoots } \\
\hline IBA $1+\mathrm{GA}_{3} 0.1$ & $20.0 \mathrm{c}$ & $2.8 \mathrm{c}$ & $11.2 \mathrm{~b}$ & $9.8 \mathrm{c}$ \\
\hline $\mathrm{NAA} 1+\mathrm{GA}_{3} 0.1$ & $60.0 \mathrm{a}$ & $2.6 \mathrm{c}$ & $22.0 \mathrm{a}$ & $11.3 \mathrm{~b}$ \\
\hline \multicolumn{5}{|c|}{ Shoots after 3 months of CS } \\
\hline IBA $1+\mathrm{GA}_{3} 0.1$ & $0.0 \mathrm{~d}$ & - & - & - \\
\hline $\mathrm{NAA} 1+\mathrm{GA}_{3} 0.1$ & $40.0 \mathrm{~b}$ & $4.8 \mathrm{a}$ & $13.4 \mathrm{~b}$ & $12.4 \mathrm{ab}$ \\
\hline \multicolumn{5}{|c|}{ Shoots after 6 months of CS } \\
\hline IBA $1+\mathrm{GA}_{3} 0.1$ & $0.0 \mathrm{~d}$ & - & - & - \\
\hline $\mathrm{NAA} 1+\mathrm{GA}_{3} 0.1$ & $40.0 \mathrm{~b}$ & $3.5 \mathrm{~b}$ & $19.8 \mathrm{a}$ & $13.4 \mathrm{a}$ \\
\hline
\end{tabular}

*PGR - Plant growth regulator; ${ }^{1}$ Mean values of rooting parameters followed by the same lowercase letters within the same column are not significantly different according to Duncan's Multiple Range Test at $\mathrm{P}<0.05$

Besides establishing an efficient protocol for in vitro propagation, another aim of this study was to examine the possibility of mid-term conservation of 'Crvena Ranka' under slow growth conditions, which can promote germplasm exchange and rapid propagation when necessary. Slow growth storage is based on the reduction in the metabolic activity of in vitro cultures by modifying the culture medium and/or the culture conditions (Lambardi and Ozudogru, 2013), which enables prolongation of the interval between two successive transfers. In our experiments, we achieved slow growth by temperature reduction coupled with the incubation of culture in the dark (cold storage technique), which is the most widely used approach (Engelmann, 2011). The highest percentage of viable shoots (94\%) with a large share of fully viable plantlets $(86 \%)$ was obtained after 3 months of CS, although some of them were sprouted and etiolated (Figs. 3 and 4a). After 6 months of CS, fully viable shoots were not recorded and the incidence of complete shoot necrosis (17.5\%) was evidenced (Fig. $3)$.

Survived plantlets $(82.5 \%)$ were partially viable, with necrotic axial shoots and viable but etiolated lateral shoots (Fig. 4b). Etiolation could be caused by darkness (Engelmann, 2011). Our experiments also revealed that it was possible to store 'Crvena Ranka' shoots under cold storage conditions for six months, while a longer period of CS was not possible due to a high rate of shoot necrosis (100\%; Figs. 3 and 4c). Contrary to our results, two Italian $P$. domestica genotypes survived cold storage markedly longer, for 12 and 9 months, while P. cerasifera ones remained viable for up to 6 months (Gianní and Sottile, 2015), similar to our results for 'Crvena Ranka' shoots. Varying results indicate that the cold storage success of different Prunus cultivars is strongly affected by genotype. 


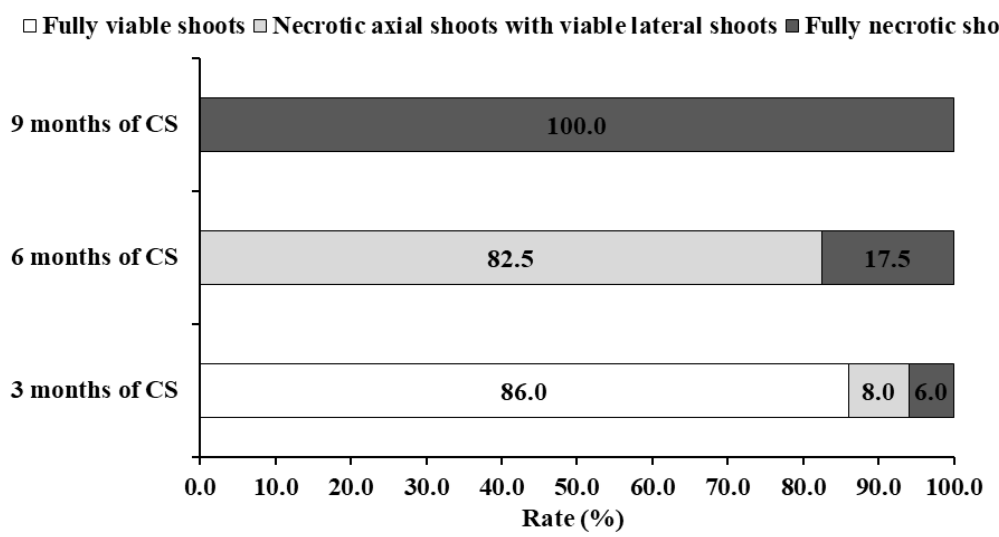

Figure 3. Viability of 'Crvena Ranka' shoots after three, six and nine months of cold storage
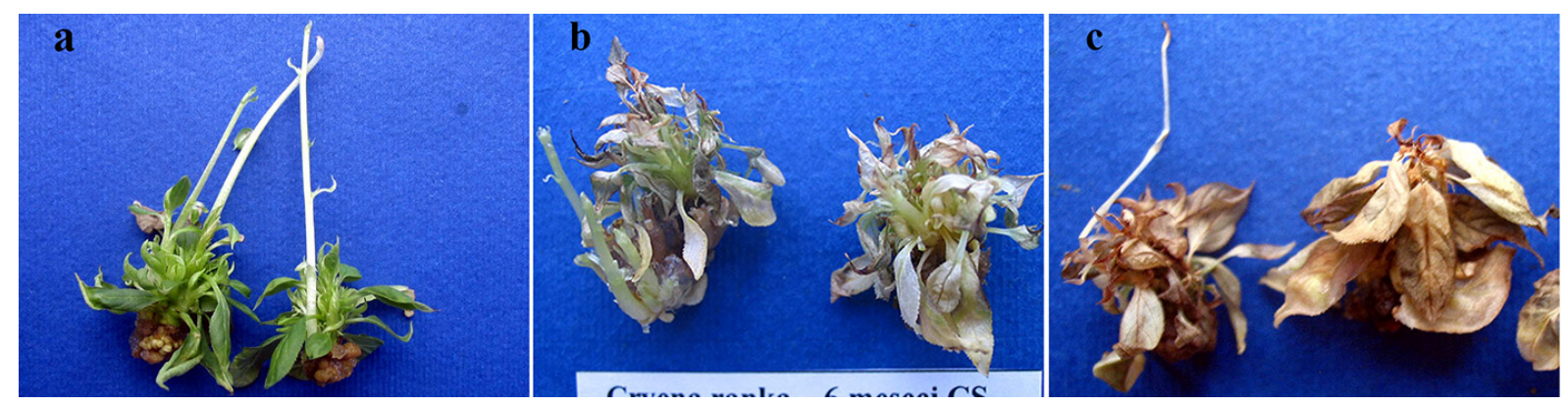

Figure 4. Shoots of 'Crvena Ranka' after three (a), six (b) and nine months (c) of cold storage

\section{Conclusions}

The presented protocol for the in vitro propagation of autochthonous plum 'Crvena Ranka', involving slight improvements in the multiplication and rooting stages, the introduction of new plant growth regulators and/or variations in their concentrations during subcultivation, can find practical application in commercial micropropagation. The resultson the cold storage of in vitro shoots at $5{ }^{\circ} \mathrm{C}$ are fairly encouraging and provide a firm base for further optimization and development of the efficient slow growth protocol for the conservation of this valuable plum genotype.

\section{Acknowledgments}

This work was partially funded by the Ministry of Education, Science and Technological Development of the Republic of Serbia (Agreement on the realization and financing of the scientific research work of the Fruit Research Institute in 2020, No. 451-03-68/202014/200215) and the Scientific Fund of the Republic of Serbia (program PROMIS, project CryoPlum).

\section{References}

Chauhan, R., Singh, V., Quraishi, A. (2019). In vitro conservation through slow-growth storage. In Faisal M., Alatar A.A. (eds.), Synthetic Seeds: Germplasm regeneration, preservation and prospects, Springer Nature, Switzerland, 397-416 pp.

Debnath, S.C. (2004). Clonal propagation of dwarf raspberry (Rubus pubescens Raf.) through in vitro axillary shoot proliferation. Plant Growth Regulation, 43, 179-186.

Engelmann F. (1997). In vitro conservation methods. In FordLloyd B.V., Newburry H.J., Callow J.A. (eds.), Biotechnology and plant genetic resources. Conservation and use, CABI, Wallingford, 119-162 pp.
Engelmann, F. (2011). Use of biotechnologies for the conservation of plant biodiversity. In Vitro Cellular and Developmental Biology-Plant, 47: 5-16.

Gianní, S., Sottile, F. (2015). In vitro storage of plum germplasm by slow growth. Horticultural Science, 42, 6169.

Glišić, I.S. (2015): Biological and pomological characteristics of promising plum (Prunus domestica L.) genotypes developed at the Fruit Research Institute, Čačak. PhD thesis, University of Belgrade, Faculty of Agriculture, 1196. (in Serbian)

Grant N.J., Hammat N. (1999): Increased root and shoot production during micropropagation of cherry and apple rootstocks: effect of subculture frequency. Tree Physiology, 19, 899-903.

Hamad, A.M., Taha, R.M. (2008). Effect of sequential subcultures on in vitro proliferation capacity and shoot formation pattern of pineapple (Ananas comosus L. Merr.) over different incubation periods. Scientia Horticulturae, 117, 329-334.

Hussain, T.M., Chandrasekhar, T., Gopal, G.R. (2007). High frequency shoot regeneration of Sterculia urens Roxb. an endangered tree species through cotyledonary node cultures. African Journal of Biotechnology, 6, 1643-1649.

Ibáñez, A., Valero, M., Morte, A. (2003). Influence of cytokinins and subculturing on proliferation capacity of single axillary bud microcuttings of Vitis vinifera L. cv. Napoleón. Anales de Biología, 25, 81-90.

Lambardi, M., Ozudogru, E.A. (2013). Advances in the safe storage of micropropagated woody plants at low temperature. Acta Horticulturae, 988, 29-42.

Milošević, T., Milošević, N. (2012). Phenotypic diversity of autochthonous European (Prunus domestica L.) and Damson (Prunus insititia L.) plum accessions based on multivariate analysis. Horticultural Science, 39, 8-20.

Milošević, T., Milošević, N., Mratinić, E. (2010). Morphogenic variability of some autochthonous plum cultivars in western Serbia. Brazilian Archives of Biology and Technology, 53(6), 1293-1297.

Murashige, T., Skoog, F. (1962). A revised medium for rapid growth and bio assays with tobacco tissue cultures. Physiologia Plantarum, 15, 473-497. 
Popović, B., Nikićević, N., Tešević, V., Urošević, I., Mitrović, O., Kandić, M. (2015): Sensory properties of plum brandies obtained by blending distillates of plum cultivar 'Crvena Ranka' and other cultivars. Journal of Pomology, 49(191/192), 99-105. (in Serbian)

Rajasekharan, P.E., Sahijram, L. (2015). In vitro conservation of plant germplasm. In Bahadur B., Venkat Rajam M., Sahijram L., Krishnamurthy K. (eds.), Plant biology and biotechnology, Springer, New Delhi, 417-443 pp.

Ružić, Đ., Cerović, R., Vujović, T. (2010). Establishment of aseptic culture in vitro for new vegetative rootstocks for cherry, pear and plum. Journal of Pomology, 44(169/170), 35-41. (in Serbian)

Sonnino A. (2017). International instruments for conservation and sustainable use of plant genetic resources for food and agriculture: an historical appraisal. Diversity, 9, 50.

Tian, L., Sibbald, S., Subramanian, J., Svircev, A. (2007). Characterization of Prunus domestica L. in vitro regeneration via hypocotyls. Scientia Horticulturae, 112, 462-466.

Vujović, T., Ružić, Đ., Cerović, R. (2012). In vitro shoot multiplication as influenced by repeated subculturing of shoots of contemporary fruit rootstocks. Horticultural Science, 39(3), 101-107.

Vujović, T., Ružić, Đ., Cerović, R. (2013). Micropropagation in vitro of sour cherry Čačanski Rubin (Prunus cerasus L.). Journal of Pomology, 47(183/184), 109-119. (in Serbian)

Vujović, T., Marjanović, T., Ružić, Đ., Glišić, I. (2018). In vitro propagation of plum rootstocks. Journal of Pomology, 52(203/204), 91-97.

Wolella E.K. (2017). Surface sterilization and in vitro propagation of Prunus domestica L. cv. Stanley using axillary buds as explants. Journal of Biotech Research, 8, 18-26. 